\title{
Shallow patch reefs as alternative habitats for early juveniles of some mangrove/seagrass-associated fish species in Bermuda
}

\author{
C.M. Huijbers, M.G.G. Grol \& I. Nagelkerken \\ Department of Animal Ecology and Ecophysiology, Institute for Wetland and Water Research, Faculty of Science, \\ Radboud University, Toernooiveld 1, 6525 ED Nijmegen, The Netherlands; i.nagelkerken@science.ru.nl
}

Received 10-VII-2007. C Corrected 05-XI-2007. Accepted 13-II-2008.

\begin{abstract}
Various coral reef fish species are highly associated with putative nursery habitats like mangroves and seagrass beds during their juvenile life stage (i.e., 'nursery species'). Little is known, however, of the degree to which they can use other habitat types as juvenile habitat. In this study we investigated whether some nursery species can utilise alternative juvenile habitats when mangroves and seagrass habitats are not readily available. Visual census surveys were carried out in six different coastal habitat types on the Western Atlantic island of Bermuda, and densities of early juveniles $(<4 \mathrm{~cm})$ were quantified for four nursery species and compared to that of four non-nursery species. Early juveniles of the nursery species Haemulon flavolineatum and Scarus iserti were observed in a variety of habitat types, consisting of their common juvenile habitats (mangroves, seagrass beds and undercut notches in large boulders) as well as of non-typical juvenile habitats (shelf patch reefs). Two other nursery species, Haemulon sciurus and Lutjanus griseus, were only present in the mangroves, seagrass and boulder habitats. All non-nursery species were only observed on the shelf patch reefs. Our findings suggest that some nursery species are flexible in their choice of early juvenile habitat, while other nursery species are more dependent on mangroves and seagrass beds even when these habitats are locally scarce. Rev. Biol. Trop. 56 (Suppl. 1): 161-169. Epub 2008 May 30.
\end{abstract}

Key words: juvenile habitat use, tropical coastal habitats, coral reef fish, Caribbean.

The majority of coral reef fish species have a pelagic larval stage, during which larvae develop into excellent swimmers (Leis 2006). They use this ability, in combination with sensory mechanisms, to actively locate suitable settlement habitats (Stobutzki and Bellwood 1994). After the settlement stage, recruitment takes place when individuals establish themselves in the juvenile population (Kaufman et al. 1992). The majority of coral reef fish species have a two-phase life cycle where larvae settle directly in the adult habitat - the coral reef. Others, however, have a three-phased life cycle in which larvae settle in a habitat different than that of the adults (Adams and Ebersole 2002, Cocheret de la Morinière et al. 2002). Adams et al. (2006) defined these species as ontogenetic shifters. Ontogenetic shifters in tropical coastal habitats have also been called 'nursery species' (sensu Nagelkerken et al. 2000a), of which the juveniles grow up in sheltered habitats like seagrass beds and mangroves. These putative nurseries are assumed to enhance the density, growth and survival of juvenile fish compared to the coral reef (Beck et al. 2001, Gillanders et al. 2003, Heck et al. 2003). Nagelkerken et al. (2000a) identified at least 17 nursery species, mainly belonging to the families Haemulidae, Lutjanidae and Scaridae. The dependence on mangrove/seagrass habitats appears to be large for some of these species, since absence of embayments or lagoons harbouring these putative nurseries resulted in adult densities of some species being significantly lower on the adjacent coral reef (Nagelkerken et al. 2002, Dorenbosch et al. 2004, Mumby et al. 2004). 
Coral reefs and adjacent back-reef/lagoonal habitats vary in geomorphology, and therefore in their suitability as early juvenile habitats for fishes. Seagrass beds and mangroves offer favourable conditions for the survival of newly settled fish, such as availability of shelter, lower predator abundance and a high supply of food (Parrish 1989, Laegdsgaard and Johnson 2001, Verweij et al. 2006). For nursery species, mainly the late juvenile and adult life stages have been studied and little is known about the early juvenile phase directly after settlement. Adams and Ebersole (2002) and Pollux et al. (2007) showed that some fish species (Lutjanus apodus and Ocyurus chrysurus) settle directly in back-reef or lagoonal habitats, such as seagrass beds and mangroves. Although previous studies have shown that larger juveniles of various nursery species depend on mangrove/ seagrass presence (Parrish 1989, Nagelkerken et al. 2000a, 2000b, Mumby et al. 2004, Adams et al. 2006), this may not be the case for early juveniles of these species. An alternative possibility is that larvae of nursery species recruit in back-reef as well as in coral reef habitats, but due to higher predation on the reef directly after settlement (Shulman 1985, Chittaro et al. 2005), early juveniles are predominantly observed in back-reef habitats.

In the current study, we investigated whether four selected nursery species also occur as early juveniles on the coral reef. The island of Bermuda was chosen as the study area because relatively little suitable seagrass habitat and almost no mangroves are present, in contrast to a very large surface area of shallow shelf-reefs. This situation is different from other regions in the Western Atlantic where seagrass beds and mangroves are readily available, and the study thus tests a situation where early juveniles have few possibilities to recruit in the habitats most frequently used in other areas. The objective of the present study was to determine the degree to which mangrove/seagrass-associated nursery species can use shallow coral reefs as alternative early juvenile habitats in situations where mangroves and seagrass beds are not readily available.

\section{MATERIALS AND METHODS}

This study was carried out in November 2005 on the islands of Bermuda, located in the Western Atlantic Ocean. Bermuda is an archipelago consisting of more than 100 islands (referred to hereafter as 'island'; $32^{\circ}$

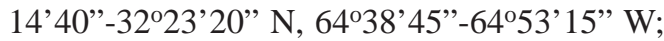
Fig. 1), with a landmass of only 5,560 ha. The island is volcanic in origin and is situated on a shallow ( $<10 \mathrm{~m}$ depth) and large (about 54,331 ha, excluding the island) insular shelf (pers. comm. K. Coates, S. Manuel, T. Murdoch and M. Shailer, Department of Conservation Services, Bermuda). Shallow patch reefs are found throughout the shelf, and at its edge the shelf is surrounded by deeper fringing coral reefs. The shoreline mangrove forests, dominated by Rhizophora mangle, are not well-developed but do provide some sheltered fish habitat. Total mangrove surface area is only about 17.5 ha (Anderson et al. 2001), but this includes non-functional mangroves (i.e., mangroves not connected to the sea or not inundated). Thalassia testudinum, Syringodium filiforme, Halodule wrightii, and Halophila decipiens are the four main seagrass species found in the seagrass beds of Bermuda's embayments as well as on the sandy shelf close to the shoreline (Fig. 1). These seagrass meadows are declining rapidly and now encompass an area of 1,625 ha, of which approximately 1,000 ha is found on the shallow shelf (Murdoch et al. 2007). The latter harbour low densities of fish compared to the seagrass beds located in the embayments (pers. observ.) and were therefore not included.

Visual census surveys were performed to determine the number of early juveniles present in six different habitat types (Fig. 1): mangroves (MG) (two sites), seagrass beds (SG) (two sites), submarine undercut notches in large boulders standing in the water along the shoreline (NT) (one site), patch reefs on the interior part of the shelf close (150 - $1600 \mathrm{~m})$ to shore (SC) (six sites; range in live coral cover: 5.2 - 24.4\%), patch reefs on the shelf break close (250 - $350 \mathrm{~m}$ ) to shore (SBC) (three sites; 

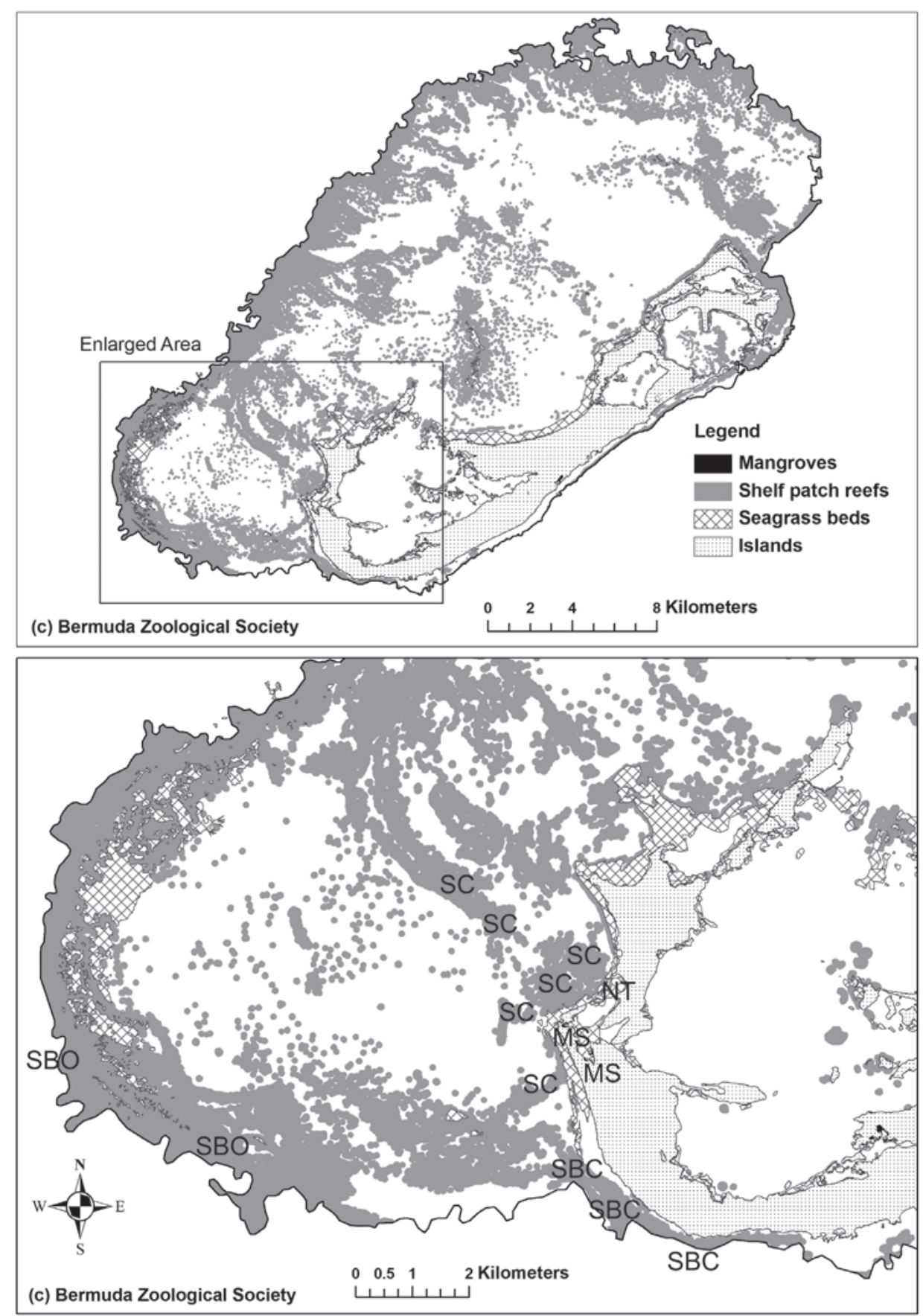

Fig. 1. Bermuda (upper panel) and enlargement of the western part of the islands (lower pannel) with all sites in the habitat types where visual census surveys were performed (adapted from Murdoch et al. 2007). SBO = patch reef on the shelf break offshore, SBC = patch reef on the shelf break close to shore, SC = patch reef on the inner shelf close to shore, MS = mangrove and seagrass sites, NT = rocky coastline with notches. The outer line of the shelf represents the $10 \mathrm{~m}$ depth contour. 
coral cover: 43.8 - $78.3 \%$ ), and patch reefs on the shelf break offshore (6.3 - $9.0 \mathrm{~km})$ (SBO) (two sites; coral cover: 29.8 - 50.4\%). The first three habitats types are typically used by nursery species during their late juvenile stage (Nagelkerken et al. 2000a, 2000b, Beck et al. 2001) and are therefore called 'putative nursery habitats' hereafter. The patch reefs surveyed were never located deeper than $8 \mathrm{~m}$. Water clarity was always greater than $6 \mathrm{~m}$, extending to over $15 \mathrm{~m}$ on most reef transects.

Fish counts were done during daytime (between 11:00 and 16:00) while snorkelling (in the mangroves and seagrass beds) or by SCUBA diving (on the reefs and in the notches). A stationary point-count method (Polunin and Roberts 1993) was used in quadrats of 10 x $10 \mathrm{~m}$ to determine densities of early juveniles. In the mangroves, transects varied in width between 1.5 and $4.0 \mathrm{~m}$ and had a length of $10 \mathrm{~m}$ as well. Ten replicate transects per site in each habitat type were surveyed during $10 \mathrm{~min}$ by a single observer. The four selected nursery species were Scarus iserti (striped parrotfish), Haemulon flavolineatum (French grunt), Haemulon sciurus (bluestriped grunt) and Lutjanus griseus (gray snapper). The four non-nursery species were Scarus taeniopterus (princess parrotfish), Sparisoma viride (stoplight parrotfish), Sparisoma aurofrenatum (redband parrotfish) and Acanthurus bahianus (ocean surgeon). Selection of these species was based on early juveniles showing highest abundance during the sampling period and belonging to fish families that included nursery species. Settlement indicates the initial establishment of larvae onto benthic substrate (Adams et al. 2006), whereas recruitment refers to the actual establishment of recent settlers into the fish population (Caley et al. 1996). In our study the focus was on recently recruited individuals of the focal species. Sizes of early juveniles of representatives of the studied families are $<4 \mathrm{~cm}$ (Leis 1987, Tolimieri 1998, Adams and Ebersole 2002, Mateo and Tobias 2004, Rooker et al. 2004, Pollux et al. 2007), and hence their size was estimated in the size classes $<2 \mathrm{~cm}$ and $2-4 \mathrm{~cm}$. It should be noted that the present study did not attempt to determine the absolute degree of recruitment in the studied habitat, since this was not possible due to the short study period of the sampling. Specifically, we compare relative habitat use and investigated whether early juveniles of some nursery species that are associated with mangrove/seagrass habitats throughout the Caribbean are able to use alternative juvenile habitats. Even though the study period was short, presence of early juveniles of nursery species in non-mangrove/seagrass habitat would indicate a certain degree of flexibility in juvenile habitat use.

\section{RESULTS}

Early juveniles of the eight coral reef fish species showed clear differences in their distribution among habitats between nursery and non-nursery species. Early juveniles of the four selected non-nursery species, i.e., S. taeniopterus, S. viride, S. aurofrenatum and A. bahianus, were only present in patch reef habitats (Fig. 2). For the most common size class of $2-4 \mathrm{~cm}$, they were significantly more abundant on the shelf break (SBC and SBO) than on the inshore patch reefs (nested ANOVA, $\mathrm{p} \leq 0.004$ ), except for A. bahianus which was also abundant on the inner shelf close to shore. These species were never found in the putative nursery habitats (mangroves, seagrass beds and notches). In contrast, early juveniles of two nursery species, L. griseus and $H$. sciurus, predominated in seagrass beds and mangroves, and the latter species also showed a high abundance in the notches (Fig. 3). These two nursery species showed negligible to no presence of early juveniles on any of the shallow patch reefs. In contrast, the nursery species $H$. flavolineatum showed presence of early juveniles in the putative nursery habitats as well as on the patch reefs, while early juveniles of $S$. iserti were significantly more abundant on the various types of patch reefs than in the putative nursery habitats (Fig. 3). 

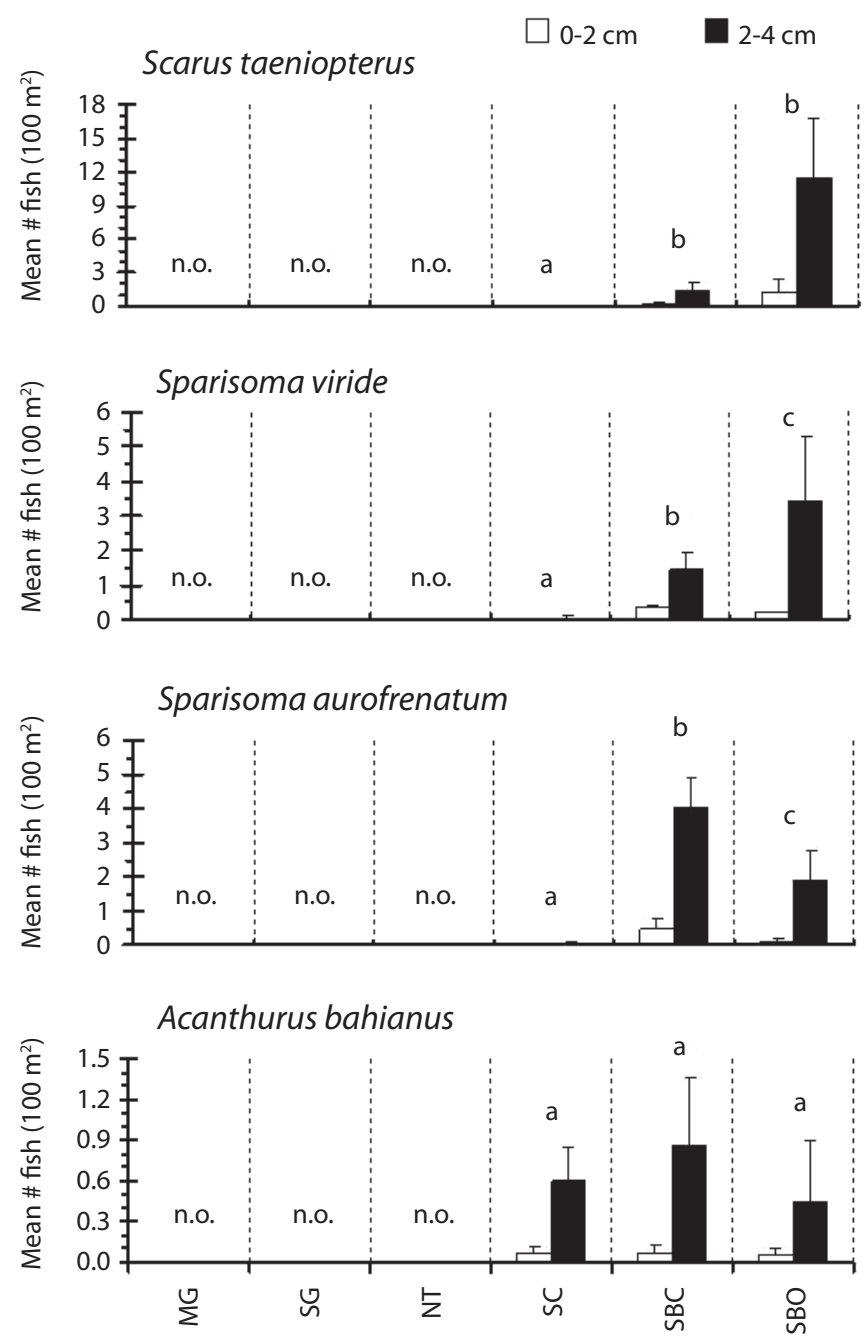

Fig. 2. Mean ( \pm S.E.) densities per $100 \mathrm{~m}^{2}$ of early juveniles of four non-nursery fish species in six different habitat types in Bermuda. n.o. = not observed. See legend of Fig. 1 for habitat abbreviations. Different letters indicate significant differences (nested ANOVA, p < 0.050) among habitats for the $2-4 \mathrm{~cm}$ size-class. Habitats showing absence of fish were excluded from the statistical analysis due to lack of variance with zero-values.

\section{DISCUSSION}

Consistent with our expectation that nonnursery fish species use the coral reef as their benthic habitat throughout all life stages, their early juveniles were only observed in the coral reef habitats. This life history strategy has been shown for these species in other studies as well (Adams and Ebersole 2002, Nagelkerken 2007,
Pollux et al. 2007). For the nursery species, there seems to be diversity in early juvenile habitat use. In western Bermuda, where sheltered mangrove sites and seagrass beds were not readily available, some nursery species (i.e., $H$. flavolineatum and $S$. iserti) were able to use shallow patch reefs as early juvenile habitats. A recent review of the literature on habitat utilisation by fish throughout the Caribbean showed 

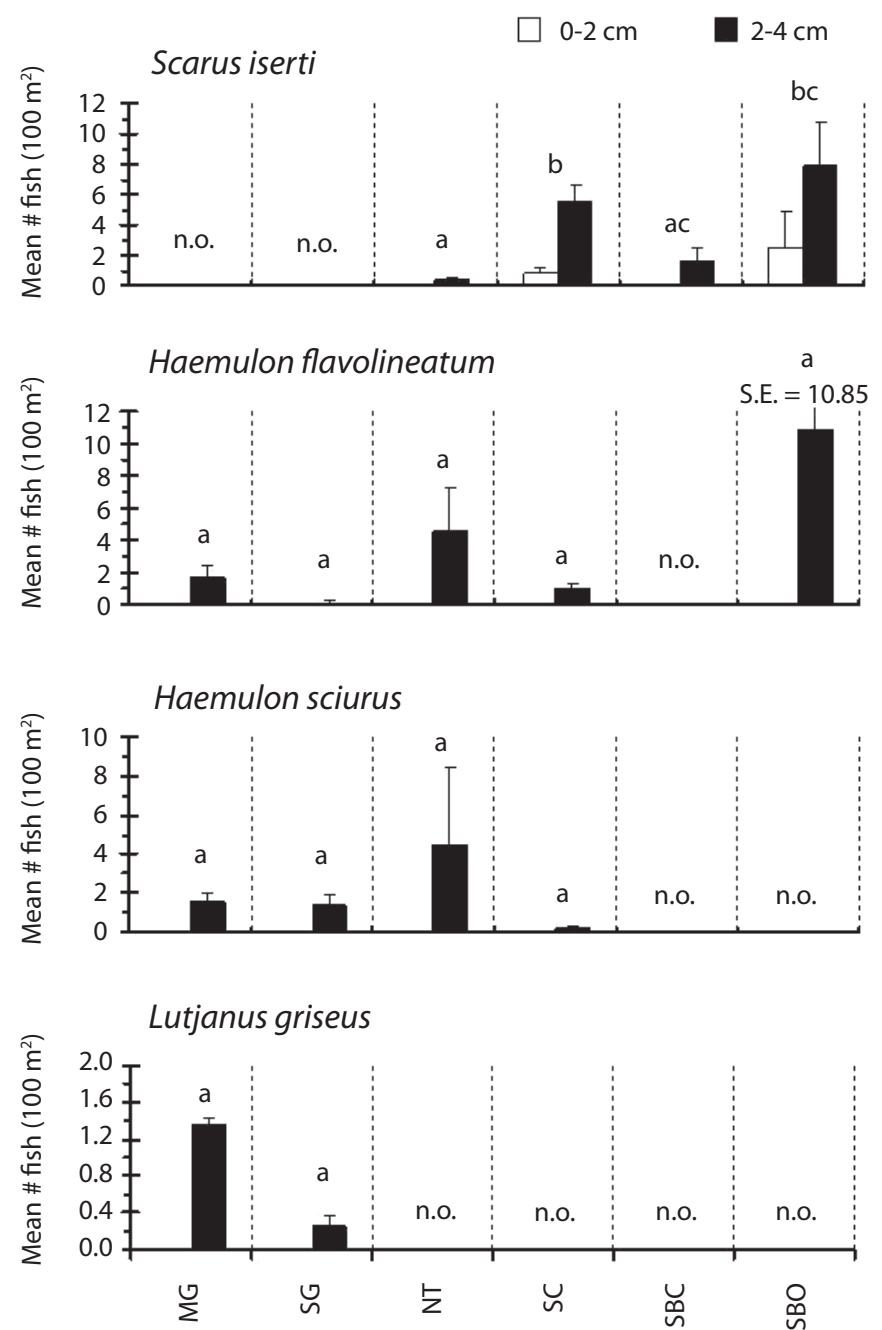

Fig. 3. Mean ( \pm S.E.) densities per $100 \mathrm{~m}^{2}$ of early juveniles of four nursery fish species in six different habitat types in Bermuda. n.o. = not observed. See legend of Fig. 1 for habitat abbreviations. Different letters indicate significant differences (nested ANOVA, p < 0.050) among habitats for the $2-4 \mathrm{~cm}$ size-class. Habitats showing absence of fish were excluded from the statistical analysis due to lack of variance with zero-values.

that juveniles of these two species have also been observed on shallow reefs in other areas where mangroves or seagrass beds do occur on a larger scale (Nagelkerken 2007). The two other nursery species $H$. sciurus and L. griseus, however, seemed to be less flexible and more dependent on the putative nursery habitats in Bermuda, even though these were not extensively available. The review of Nagelkerken
(2007) showed that (early) juveniles of these two species are (almost) never found in coral reef habitats elsewhere in the Caribbean, supporting the high dependence of these two species on these putative nursery habitats.

In concordance with an earlier study (Pollux et al. 2007) we demonstrate here that early juvenile habitat use among nursery species is not random. Instead, species-specific 
patterns of early juvenile habitat use were observed. On most Caribbean islands postlarval fishes must cross a coral reef or shelf before they can enter lagoons or embayments harbouring mangroves, seagrass and algal beds where they can recruit (Adams and Ebersole 2002). In contrast to islands where the coral reef is situated on a slope close to shore, the coastal area of Bermuda consists of a very large shallow shelf, where some nursery species like $H$. flavolineatum and $S$. iserti appear to find suitable recruitment habitats at varying distances from shore. These two species might show a trade-off strategy where direct settlement in the first encountered habitat (i.e. patch reefs on the shelf break offshore), but with a potentially higher predation risk, is possibly weighed against settling in or finding other more appropriate habitats located further inshore. This contrasts with the observed patterns for $H$. sciurus and $L$. griseus which were never found on the shelf break, suggesting species-specific mechanisms in habitat selection by nursery species. Recent studies show that coral reef fishes can use environmental cues to actively locate suitable settlement habitats, including mangroves and seagrass beds (Kingsford et al. 2002, Lecchini et al. 2005, Huijbers et al. 2008), yet it is unknown if early juveniles are able to use these cues to distinguish between different habitat characteristics such as presence of suitable shelter, availability of food and predator abundances.

In conclusion, the present study shows that some nursery species can be flexible in their choice of early juvenile habitats. While early juveniles of $L$. griseus and $H$. sciurus prevailed in their common putative nursery habitats like seagrass beds, mangroves and notches, two other recognised nursery species, H. flavolineatum and $S$. iserti, seem to be more opportunistic in environments where a variety of shallowwater habitats exist in close proximity to each other. Early juveniles of four non-nursery fish species were never found in sheltered putative nursery habitats in the specific setting of habi- tats as occurring in Bermuda.

\section{ACKNOWLEDGMENTS}

This project was funded by the Netherlands Organisation for Scientific Research (NWO) through a VIDI grant to I. Nagelkerken. The field work was supported by the Department of Conservation Services (Ministry of Environment, Telecommunications, and e-Commerce). We thank K. Coates, T. Murdoch, S. Manuel and A. Nash of the Department of Conservation Services for their hospitality, logistic support and provision of research materials, and M. Shailer of the same department for preparing the maps. This is Centre for Wetland Ecology publication No. 497.

\section{RESUMEN}

Varias especies de peces que habitan los arrecifes de coral están asociadas con los hábitats que funcionan como viveros, por ejemplo los manglares y áreas de pastos marinos, durante la etapa juvenil de su vida (i.e., 'especies de vivero’). Sin embargo, poco se sabe de si pueden utilizar otros tipos de hábitat en esta etapa. En este estudio investigamos si algunas 'especies de vivero' pueden utilizar hábitats alternativos durante la etapa juvenil, cuando se les dificulta el acceso a manglares y pastos marinos. Se llevaron a cabo censos visuales en seis tipos de hábitat costero en la Isla Bermuda (Atlántico Oeste), y las densidades de los jóvenes tempranos $(<4 \mathrm{~cm}$ ) de cuatro 'especies de vivero' fueron cuantificadas y comparadas con cuatro especies que no son de viveros. Los jóvenes tempranos de las especies de vivero, Haemulon flavolineatum y Scarus iserti, fueron observados en una variedad de tipos de hábitats, entre los cuales se encontraban los hábitats comunes para los jóvenes (manglares, parches de pastos marinos y debajo de cornisas de rocas grandes), así como hábitats que no son típicos para los jóvenes (parches arrecifales). Otras dos especies de vivero, Haemulon sciurus y Lutjanus griseus, solo se encontraron en manglares, pastos marinos y rocas. Todas las especies que no son de vivero fueron observadas solamente en los parches arrecifales. Estos resultados sugieren que algunas especies de vivero son flexibles a la hora de elegir un hábitat en la etapa de jóvenes tempranos, mientras que otras tienen una mayor dependencia de los manglares y los parches de pastos marinos, aun cuando estos hábitats son escasos.

Palabras clave: uso de hábitats por juveniles, hábitats cos- 
teros tropicales, peces de arrecifes coralinos, Caribe

\section{REFERENCES}

Adams, A.J. \& J.P. Ebersole. 2002. Use of back-reef and lagoon habitats by coral reef fishes. Mar. Ecol. Prog. Ser. 228: 213-226.

Adams, A.J., C.P. Dahlgren, G.T. Kellison, M.S. Kendall, C.A. Layman, J.A. Ley, I. Nagelkerken, \& J.E. Serafy. 2006. Nursery function of tropical back-reef systems. Mar. Ecol. Prog. Ser. 318: 287-301.

Anderson, C., H. DeSilva, J. Furbert, A. Glasspool, L. Rodrigues, W. Sterrer \& J. Ward. 2001. Bermuda Biodiversity Country Study. Bermuda Biodiversity Project, Bermuda Aquarium Museum and Zoo, Flatts, Bermuda.

Beck, M.W., K.L. Heck, K.W. Able, D.L. Childers, D.B. Eggleston, B.M. Gillanders, B. Halpern, C.G. Hays, K. Hoshino, T.J. Minello, R.J. Orth, P.F. Sheridan \& M.R. Weinstein. 2001. The identification, conservation, and management of estuarine and marine nurseries for fish and invertebrates. Bioscience 51: 633-641.

Caley, M.J., M.H. Carr, M.A. Hixon, T.P. Hughes, G.P. Jones \& B.A. Menge. 1996. Recruitment and the local dynamics of open marine populations. Annu. Rev. Ecol. Syst. 27: 477-500.

Chittaro, P.M., P. Usseglio \& P. Sale. 2005. Variation in fish density, assemblage composition and relative rates of predation among mangrove, seagrass and coral reef habitats. Env. Biol. Fish. 72: 175-187.

Cocheret de la Morinière, E., B.J.A. Pollux, I. Nagelkerken \& G. van der Velde. 2002. Post-settlement life cycle migration patterns and habitat preference of coral reef fish that use seagrass and mangrove habitats as nurseries. Estuar. Coast. Shelf Sci. 55: 309-321.

Dorenbosch, M., M.C. van Riel, I. Nagelkerken \& G. van der Velde. 2004. The relationship of reef fish densities to the proximity of mangrove and seagrass nurseries. Estuar. Coast. Shelf. Sci. 60: 37-48.

Gillanders, B.M., K.W. Able, J.A. Brown, D.B. Eggleston \& P.F. Sheridan. 2003. Evidence of connectivity between juvenile and adult habitats for mobile marine fauna: an important component of nurseries. Mar. Ecol. Prog. Ser. 247: 281- 295.

Heck, K.L., G. Hays \& R.J. Orth. 2003. Critical evaluation of the nursery role hypothesis for seagrass meadows. Mar. Ecol. Prog. Ser. 253: 123-136.
Huijbers, C.M., E.M. Mollee, I. Nagelkerken. 2008. Postlarval French grunts (Haemulon flavolineatum) distinguish between seagrass, mangrove and coral reef water: implications for recognition of potential nursery habitats. J. Exp. Mar. Biol. Ecol. 357: 134-139.

Kaufman, L., J. Ebersole, J. Beets \& C.C. McIvor. 1992. A key phase in the recruitment dynamics of coral reef fishes: post-settlement transition. Env. Biol. Fish. 34: 109-118.

Kingsford, M.J., J.M. Leis, A. Shanks, K.C. Lindeman, S.G. Morgan \& J. Pineda. 2002. Sensory environments, larval abilities and local self-recruitment. Bull. Mar. Sci. 70: 309-340.

Laegdsgaard, P. \& C. Johnson. 2001. Why do juvenile fish utilise mangrove habitats? J. Exp. Mar. Biol. Ecol. 257: 229-253.

Lecchini, D., J. Shima, B. Banaigs \& R. Galzin. 2005 Larval sensory abilities and mechanisms of habitat selection of a coral reef fish during settlement. Oecologia 143: 3236-334.

Leis, J.M. 1987. Review of the early life history of tropical groupers (Serranidae) and snappers (Lutjanidae), pp 189-237. In J.L. Polovina \& S. Ralston (eds.). Tropical Snappers and Groupers: Biology and Fisheries Management. Westview, London

Leis, J.M. 2006. Are larvae of demersal fishes plankton or nekton? Adv. Mar. Biol. 51: 57-141.

Mateo, I. \& W.J. Tobias. 2004. Survey of nearshore fish communities on tropical backreef lagoons on the Southeastern coast of St. Croix. Caribb. J. Sci. 40: 327-342.

Mumby, P.J., A.J. Edwards, J.E. Arias-Gonzalez, K.C. Lindeman, P.G. Blackwell, A. Gall, M.I. Gorczynska, A.R. Harborne, C.L. Pescod, H. Renken, C.C.C. Wabnitz \& G. Llewellyn. 2004. Mangroves enhance the biomass of coral reef fish communities in the Caribbean. Nature 427: 533-536.

Murdoch, T.J.T., A.F. Glasspool, M. Outerbridge, J. Ward, S. Manuel, J. Gray, A. Nash, K.A. Coates, J. Pitt, J.W. Fourqurean, P.A. Barnes, M. Vierros, K. Holzer \& S.R. Smith. 2007. Large-scale decline in offshore seagrass meadows in Bermuda. Mar. Ecol. Prog. Ser. 339: 123-130.

Nagelkerken, I. 2007. Are non-estuarine mangroves connected to coral reefs through fish migration? Bull. Mar. Sci. 80: 595-607.

Nagelkerken, I., M. Dorenbosch, W.C.E.P. Verberk, E. Cocheret de la Morinière \& G. van der Velde. 2000a. 
Importance of shallow-water biotopes of a Caribbean bay for juvenile coral reef fishes: patterns in biotope association, community structure and spatial distribution. Mar. Ecol. Prog. Ser. 202: 175-192.

Nagelkerken, I., G. van der Velde, M.W. Gorissen, G.J. Meijer, T. van 't Hof \& C. den Hartog. 2000b. Importance of mangroves, seagrass beds and the shallow coral reef as a nursery for important coral reef fishes, using a visual census technique. Estuar. Coast. Shelf Sci. 51: 31-44.

Nagelkerken, I., C.M. Roberts, G. van der Velde, M. Dorenbosch, M.C. van Riel, E. Cocheret de la Morinière \& P.H. Nienhuis. 2002. How important are mangroves and seagrass beds for coral-reef fish? The nursery hypothesis tested on an island scale. Mar. Ecol. Prog. Ser. 244: 299-305.

Parrish, J.D. 1989. Fish communities of interacting shallow-water habitats in tropical oceanic regions. Mar. Ecol. Prog. Ser. 58: 143-160.

Pollux, B.J.A., W.C.E.P. Verberk, M. Dorenbosch, E. Cocheret de la Morinière, I. Nagelkerken \& G. van der Velde. 2007. Habitat selection during settlement of three Caribbean coral reef fishes: Indications for directed settlement to seagrass beds and mangroves. Limnol. Oceanogr. 52: 903-907.
Polunin, N.V.C. \& C.M. Roberts. 1993. Greater biomass and value of target coral-reef fishes in two small Caribbean marine reserves. Mar. Ecol. Prog. Ser. 100: 167-176.

Rooker, J.R., A.M. Landry, B.W. Geary \& J.A. Harper. 2004. Assessment of a shell bank and associated substrates as nursery habitat of postsettlement red snapper. Estuar. Coast. Shelf Sci. 59: 653-661.

Shulman, M.J. 1985. Recruitment of coral-reef fishes - effects of distribution of predators and shelter. Ecology 66: 1056-1066.

Stobutzki, I.C. \& D.R. Bellwood. 1994. An analysis of the sustained swimming abilities of presettlement and postsettlement coral-reef fishes. J. Exp. Mar. Biol. Ecol. 175: 275-286.

Tolimieri, N. 1998. Effects of substrata, resident conspecifics and damselfish on the settlement and recruitment of the stoplight parrot fish, Sparisoma viride. Env. Biol. Fish. 53: 393-404.

Verweij, M.C., I. Nagelkerken, D. de Graaf, M. Peeters, E.J. Bakker \& G. van der Velde. 2006. Structure, food and shade attract juvenile coral reef fish to mangrove and seagrass habitats: a field experiment. Mar. Ecol. Prog. Ser. 306: 257-268. 
